\title{
Challenges Faced by IIUM Postgraduate Students in Conducting the Qur'an Memorization and Working for Living during their Study Period
}

\author{
M Husnaini ${ }^{1 *}$, Noor Amili'2 ${ }^{2}$ Betania Kartika ${ }^{3}$, Dawood Abdulmalek Yahya Al-Hidabi ${ }^{4}$, Halim bin \\ Ismail $^{5}$ \\ 1,2,3,4,5 International Islamic University Malaysia. \\ *e-mail: 1*hus surya06@yahoo.co.id, ${ }^{2}$ nooramili@iium.edu.my \\ 3betania@iium.edu.my,
}

\section{Article Information \\ Received: September 29, 2021 \\ Revised: November 25, 2021 \\ Accepted: December 30, 2021 \\ Online: March 03, 2022}

\section{Keywords}

The Qur'an, memorization, working activities, postgraduate students, International Islamic University Malaysia

\begin{abstract}
This study looks at the difficulties that IIUM postgraduate students have when memorizing the Qur'an and working at the same time during their studies. The goal of this study is to find out how IIUM postgraduate students balanced Qur'an memorization and working activities during their studies, to identify the difficulties they faced, and to find out how they balanced Qur'an memorization and working activities. A case study was used in this study to create a qualitative design. The data was collected via methodical triangulation, and the data was gathered through verbal interviews. Two postgraduate students from IIUM were chosen to be interviewed. Thematic analysis was used to examine the data. The keywords were determined once the data from the interviews were transcribed. The researchers then identified the theme for further investigation before analyzing the data. The findings revealed that these students value Qur'an memorization but that there is no timetable for memorizing the whole Qur'an due to their busy schedules.
\end{abstract}

\section{INTRODUCTION}

There has been a surge in interest in memorizing the Qur'an. It is because many people have become increasingly conscious of the significance and positive impact of memorizing the Qur'an in the life of a Muslim. As a result, they are motivated to seek out people or programs that will help them improve their Qur'an recitation and memory skills.

In recent years, there has been an increase in the number of persons memorizing the Qur'an in schools, mosques, and households. The ultimate goal of memorizing the Qur'an should be to satisfy humanity's innate urge to seek Allah's pleasure. Memorize the Qur'an, as Prophet Muhammad advised, for Allah would not punish the heart that has the Qur'an. Hamzah (2005) defines formalized formally. This phrase emphasizes Allah's guarantee to people who remember the Qur'an that they would not be punished in the hereafter.

The journey of memorizing the Qur'an may not always be straightforward and smooth. However, Allah has guaranteed His assistance in this situation in the Qur'an. In Surah Ali Imran: 159 and 160, Allah encourages people to rely on Him because He is the only one who can aid us when we are in need. "Have faith in Allah. Allah appreciates people who put their trust in Him. Nobody can defeat you if Allah is with you. If He abandons you, who is there to aid you after that?" These verses say unequivocally that 
students must trust Allah and rely on His assistance when reciting and remembering the Qur'an (Ali, 1996).

Furthermore, memorizing the Qur'an has been prioritized above all other courses in Islamic education. As a result, memorizing the Qur'an is the most honorable achievement a Muslim learner can attain. It is because the Qur'an is Islam's initial source of legislation. Furthermore, the Qur'an serves as the foundation for the Sunnah, the second source of legislation. These two fundamental sources of information will help humanity better grasp Islam's religion and lead himself and others.

Furthermore, the first step toward completely memorizing the Qur'an is to feel that this is the most important activity in one's life and that it will not consume one's time away from other pursuits. Allah will bless one's time, and the remainder of one's activities will not only continue but will thrive and become easier than before. A Muslim should not believe that learning the Qur'an takes a long time. No matter how much time is spent reading, contemplating, and memorizing, it does not reduce one's time; rather, it raises the quality to do many more things.

An example might be as follows: if one has time to study in order to pass the exam and uses some of that time to memorize the Qur'an, what will be the outcome? First, memorizing the Qur'an will improve his grasping ability, broaden his thinking capacity, and provide him with a strong memory, understanding, and comprehension ability. Second, when one memorizes some surahs, they will realize that they can comprehend their research in less time than they previously could. Third, one's test performance will be substantially improved since memorizing the Qur'an provides psychological and mental stability and gives you the confidence that Allah, not your effort or work, determines your exam

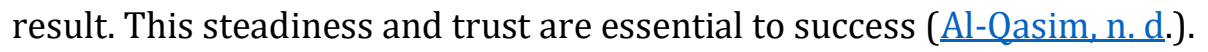

\section{The Perception of the Qur'an Memorization}

There are advantages to memorizing the Qur'an. First and foremost, memorizing the Qur'an will open all the doors to kindness. Second, memorizing (reciting) the Qur'an entails receiving ten positive

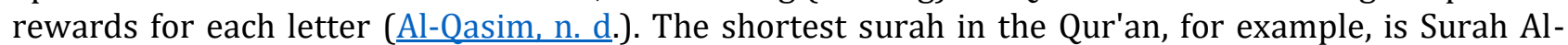
Kauthar, which has 42 letters. This surah can be recited in seconds, which implies that Allah will reward the reciter with 420 points of good actions anytime it is read, with each point of His Reward being far more valuable than the entire globe. With that said, one could ask how many blessings Allah will bestow on the reciters for their constant recitation and memorization of the Qur'an.

Third, the Qur'an contains knowledge of the world and the hereafter. It comprises various scientific, cosmological, legislative, and medical facts and clauses, regulations, and legislation that govern believers' lives and make them prosperous and sovereign (Laila, 2014). It means that when they learn the Qur'an, they are memorizing the world's largest encyclopedia. Fourth, this Qur'an, which they are memorizing today, will be their companion when they die. It will be their protector and intercessor when abandoned by those closest to them. "Read the Qur'an. It will be the intercessor of its companions on the Day of Resurrection," the Prophet (peace be upon him) remarked (Hilmi et al., 2017).

Fifth, as believers memorize the Qur'an, their expressing ability improves as a result of the classic Arabic they learn from the Qur'an (Aryati et al., 2020). By memorizing the Qur'an, one will also have a higher sense of mental health, being more stable than those who are not, because the Qur'an memorization has strengthened their cognitive power (Aziz, 2017). Sixth, the Qur'an is healing for physical and psychological ailments, with a strong favorable association between memorizing the Qur'an and the immune system in dealing with diseases such as hypertension, diabetes, and many other chronic diseases (Ma'ruf et al., 2019). If reading Surah Al-Fatihah (The Beginning) may cure a patient if Allah wills, consider how powerful memorizing the entire Qur'an can be for one's well-being. Ma'ruf et al. (2019) discovered that the health benefits of memorizing the Qur'an are not just religious rhetoric but also a reality that people experience.

\section{The Difficulties of the Qur'an Memorization}

From the study on the obstacles in memorizing Al-Qur'an, researchers have identified difficulties in the journey of memorizing the Qur'an such as 1) the tendency to forget the verses, 2) the unsupportive environment, 3) similar verses, 4) time management, 5) lack of discipline, 6) negative influences from others, 7) emotional state, 8) unfamiliarity with words of the verses, and many other challenges (Abdullah, 2021). 
Thus, by finding out the challenges behind students' motivation, this research will help to minimize the gap of the study in the field of Qur'an memorization. Tahfidz (programs are based on the parents' wish for their children to memorize the Qur'an, it is important to seek the challenges faced by students that may affect their motivation in memorization of the Qur'an (Abdullah, 2018).

\section{Tips and Practical Steps for Qur'an Memorization}

There are some prerequisites and tips in memorizing the Qur'an, knowing that to memorize the whole Al-Qur'an is a big task that its methods shall be taken into consideration. From the research done by Aziz (2017), the followings are the normative prerequisites in memorizing the Qur'an: Strong resolutions. By withstanding a strong resolution in starting to memorize the Qur'an, it will shield the individual from any weakness in facing the challenges in memorizing Al-Qur'an. As the Qur'an already mentioned, those with strong resolution in striving the world and akhirah will be given good rewards (Al-Isra': 19).

1. Patience.

2. Istiqamah (being consistent).

3. Avoiding bad behaviors.

4. Deciding a specific method in memorizing Al-Qur'an.

5. Finding a teacher or friend that wants to correct one's memorization.

6. Preserving their ablution (wudu' $u^{\prime}$ in doing memorization.

7. Limit the amount of verse to memorize each time one does the memorization.

8. Complete the memorization fully from moving to another verse to memorize.

9. Review the whole page before moving to the next Qur'an page.

10. Constantly reviewing the memorization.

11. Repeat the recitation in the head the whole day before moving to the next memorization.

Akhmar et al. (2021) also mention many other methods that needed to be taken into consideration in giving options for one to do Qur'an memorization, which is as the following:

1. Talqin method, by constantly repeating memorization in one's head before moving to the next verse.

2. Talqin and recording method, with an additional method by recording one's memorization and playing the record while depicting the memorization in the head.

3. Gesture method, by using hand and body gestures in memorizing the Qur'an with symbols related with the meaning of the verses that are memorized.

4. One day one ayāt, by slowly memorizing the verse one by one every day.

5. Understanding the meaning and context of the verse that is being memorized will give the individual a better grasp of the verse, and thus, they may remember the verse according to the meaning.

\section{International Islamic University Malaysia}

International Islamic University of Malaysia (IIUM) was built around the "Garden of Knowledge and Virtue" concept in 1983. As a result, it has become one of the prominent universities in Malaysia and internationally. Over the last 20 years, the university has hosted students from more than 92 countries. The university's specialty lies in its philosophy and curriculum, which combine rigorous academic programs with Islamic social and moral values. IIUM started its first new intake in 1983, with 153 new students. Situated at the foot of the Gombak hillside, it is about 10 kilometers from Kuala Lumpur, the capital city of Malaysia (International Islamic University of Malaysia, 2021).

The campus occupies an area of 288 hectares. The proposed built campus offers a complete range of facilities, including on-campus housing, a large library with online access, a 24-hour clinic, cafeterias, auditoriums, communication facilities, computer labs, teaching and research labs, convenience stores, a post office, and two banks. In addition, the university also provides various sports facilities such as an Olympic-sized swimming pool, two sports complexes, football fields, tennis courts, basketball courts, and more. Similar facilities are also available on the IIUM's other campus branches situated in Kuantan, Pahang, Petaling Jaya, and Selangor (International Islamic University of Malaysia, 2021). 
In International Islamic University Malaysia (IIUM), some postgraduate students memorize the Qur'an and work at the same time during their studies. As students who are required to study seriously for certain subject matter, memorizing the Qur'an is not an easy job as many of them are also coping and balancing their various activities and work outside of the campus. There is still a need for a study on the challenges faced by students in Qur'an memorization and how they overcome these challenges. Thus, this paper aims to explore the perception of IIUM postgraduate students on balancing Qur'an memorization and working activities during their study, to identify the difficulties faced by IIUM postgraduate students in managing the Qur'an memorization and working activities, and to investigate the way of postgraduate students balance their time with Qur'an memorization and working activities.

\section{METHODS}

The study's methodology was a case study with a qualitative approach. Therefore, a descriptive case study was used in this study. According to Yin (1984), an exploratory case study is designed to investigate any occurrence in the data that piques the researcher's curiosity. A researcher doing an exploratory case study on an individual's reading process, for example, may ask basic questions such as, "Does the student utilize any techniques when he reads a text?" and "If so, how?" These broad queries are intended to pave the way for future investigation of the observed event (Zainal, 2007). As a result, the method used in this study is an exploratory case study in qualitative format. On the other hand, the researchers utilized a semi-structured interview to collect data from the informants.

Furthermore, the study used a purposive sample approach, which allowed the researchers to select persons who could best understand the issue under consideration. According to Patton (2002), purposive sampling is a strategy extensively employed in qualitative research to identify and select information-rich cases to make the most use of limited resources.

This study benefited from the participation of two informants. The first source is a male master student of Islamic Revealed Knowledge (IRK) at IIUM from East Java, Indonesia. The second informant is a male-master student of IRK at IIUM from the Indonesian island of Lombok. The researchers chose these two IIUM postgraduate students since they are both IIUM postgraduate students who memorize the Qur'an while also working during their studies. The researchers intended to investigate their opinion of Qur'an memorization the challenges they had in managing Qur'an memorization, and they are practiced combining Qur'an memorization and working tasks while studying at their level. In addition, the researchers employed anomaly detection to keep the informants' information private. Informant 1 and Informant 2 are the codes used for the informants.

Furthermore, this study employs a qualitative method using a case study as the study design. On the other hand, the researchers conducted a semi-structured interview to acquire data from informants. However, the instrument's reliability and validity will be tested to see if it can help the researchers answer the study questions. This study comprises three research questions, each with a different data collection method. The phrase "reliability" refers to a notion used for testing or evaluating quantitative research, while the concept is commonly utilized in all types of research. In the qualitative paradigm, testing is considered a method of eliciting information. As a result, the quality of any qualitative study is the most important test. A solid qualitative study can assist us in "understanding a situation that would otherwise be ambiguous or confounding" (Eisner, 1991).

Meanwhile, the researchers must guarantee that the findings and interpretation are correct and valid throughout the data collecting and analysis process. According to Creswell (2005), validating findings in qualitative research entails determining the veracity or trustworthiness of the finding through procedures such as member checking or triangulation. The finding was validated using triangulation in this investigation. According to Silverman (1998), interviews are not naturally occurring; rather, they are 'constructed' by researchers, and as such, they do not allow direct access to the experiences of those investigated, whereas interviews are best employed when comprehensive information from a few specific persons is required. Interviews are also very important when seeking the opinions of specialists. Thus, in this study, interviews were employed to learn more about the students' strategies for memorizing the Qur'an.

The interviews were performed with two postgraduate students from IIUM. Interviews are ideal for learning about people's perceptions and experiences. However, because the interviewer is a participant in the molding of the dialogue, the interviewer's role must be represented in the study's 
findings. One advantage of conducting an interview is communicating that the informants' perspectives are valued and useful (Blandford, 2013). Therefore, semi-structured questions were asked in this study. The semi-structured questions allowed the researchers to conduct a systematic interview based on created questions while also soliciting additional suggestions from the informants to provide information that was not on the list of questions. The interview lasted about thirty minutes.

\section{Data Collection Procedure}

Before gathering the data, formal processes were followed. First, the researchers visited and met with the two IIUM postgraduate students to obtain permission to perform the research. The researchers then employed methodological triangulation. Denzin (1970) defines methodological triangulation as the researcher gathering data from documents, interviews, and observation. Next, the researchers conducted interviews with informants using the interview questions provided.

\section{Data Analysis}

The data was analyzed using theme analysis by the researchers. Thematic analysis is a sort of qualitative analysis, according to Boyatzis (1998). It is used to examine classifications and exhibit datarelated themes (patterns). In addition, it provides detailed illustrations of the data and addresses various topics through interpretations (Ibrahim et al., 2012). The researchers employed the theme analysis because it reflects a degree of patterns, responses, or meaning from the data connected to the study subject at hand.

Furthermore, the interview data were transcribed, and keywords were discovered. The researchers then identified the theme for further investigation before analyzing the data. Finally, all of the data from the interview methods were integrated to obtain all of the information needed to answer the study questions.

\section{Pilot Study}

The pilot study, "a small-scale trial run of all the procedures planned for use in the main study," is an important component in the data collection process (Monette et al., 2002). Pilot testing entails determining whether a survey, key informant, interview advice, or observation form will work in the "real world" by putting it to the test on a small group of individuals first. The goal is to ensure that everyone in the sample understands and understands the questions in the same way. It also allows you to double-check whether the interview questions are appropriate. You will also see how long it takes to complete the survey in real-time.

A pilot test was done between two IIUM postgraduate students in this study to determine the validity of the interview questions. First, the researchers asked all eight interview questions to the two pupils. Next, the researchers took approximately thirty minutes. Finally, the researchers taped every conversation.

\section{RESULTS}

The findings were divided into three groups based on the research topics. Every part featured themes that were explained by the themes listed below. The first segment included IIUM postgraduate students' perspectives on managing Qur'an memorization and working activities during their level of study. The second portion discussed the challenges that IIUM postgraduate students experienced in managing Qur'an memorization and work activities during their level of study. Finally, the third portion looked at how IIUM postgraduate students balanced Qur'an memorization with work activities during their level of study.

Two postgraduate students from IIUM were chosen, both of whom were men. They are IRK Kulliyyah, master pupils. The researchers employed anomalies to keep the informants' information private. Furthermore, the researchers employed codes for all informants to protect the informants' data in the interviews, specifically informants 1 and 2. As a result, the information acquired from two IIUM postgraduate students was gathered through interviews, and the researchers discovered five themes. Three themes emerged from the findings for the first study question. 
On the other hand, the second research question has only one theme. Finally, the third research topic focused on a single theme. The explanation of findings demonstrates the deep examination of themes. All the data from interviews were merged to answer the research questions.

\section{RESEARCH QUESTIONS}

\section{What is the perception of IIUM postgraduate students on balancing Qur'an memorization and working at the same time during their study period?}

Based on analysis of the data from interviews, the researchers found three themes for this research question. The first theme described that Qur'an memorization was important. The second theme showed that the beginning of the Qur'an memorization of the students had started from junior high school. Finally, the last theme for this research question reported the technique in memorizing the Qur'an was through repetition in reciting the verses.

\section{Theme 1: The Importance of Qur'an Memorization}

The Qur'an memorization is important for all Muslims, whether they are students or not. According to informant 1, the Qur'an memorization is very important in his life. He said:

Ya, kalau motivasi dari dalam, ya, memang itu tuntutan dari diri sendiri. Ya, itu bermula dari ketika remaja, ya, yang pernah saya ceritakan itu, ya, ada, ya, karena sudah pernah membuat, ya, seperti tabel-tabel seperti itu dan terbiasa, akhirnya, jadinya terbiasa untuk menghafal rutin, punya rutinitas untuk menghafal. Dan, itu memudahkan ke depan, ketika sudah lepas dari, apa, masa sekolah, sekolah menengah, itu ada kebiasaan untuk menghafal itu yang membuat memudahkan untuk kita menghafal (Informant 1/DU 8).

Translation:

Yeah, regarding internal motivation, indeed, it came from me. But, nevertheless, yes, it had started when I was a teenager, as I did tell you before, it was because I ever made some tables that helped me be accustomed to memorization by having a routine to memorize. Furthermore, it helped me for the future, when one already graduated from, what was it, school, there would be a molded custom to memorize that eased us in memorization (Informant 1/DU 8).

Moreover, informant 2 said that Qur'an memorization was his hobby and his need. He said:

Kalau pribadi saya, menghafal Al-Quran itu, selain hobi, memang kebutuhan. Kebutuhan secara pribadi, ya. Jadi, saya, selain hobi, juga karena kebutuhan. Itu menghafalkan Al-Quran, bagi saya (Informant 2/DU 6).

Translation:

Memorizing Al-Qur'an, other than a hobby, is also my need. My personal needs, to be specific. So other than a hobby, for me, it is a need. That is what memorizing Al-Qur'an meant for me (Informant 2/DU 6).

\section{Theme 2: Junior High School as the Start of Qur'an Memorization}

Based on the data gathered from the interviews with informants one and informants 2, they started to memorize the Qur'an from Junior High School. Informant 1 reported that he started from Junior High School and when he joined Musabaqah Tilawatil Qur'an (Qur'anic Recitation Competition). He said: Ya, mulainya, ya, dari... kalau kesadaran sendiri yang saya ingat memang dari kelas 2 SMP. Ya (Informant 1/DU 10)

Translation:

Yeah, it started from... if what you meant was my motivation, what I remembered was it started when I was at 2nd level of Junior High School (Informant 1/DU 10). 
And he also said:

Mulai ada tumbuh keinginan. Ya, maksudnya, betul-betul, bukan sekadar karena ini, gitu, ya. Kayak, misalnya, anak... anak SD itu, kan, mungkin karena paksaan dari guru atau karena mau nilai, gitu. Tapi kalau betul-betul mulai dari diri sendiri itu mulai dari kelas 2. Ya, meskipun di tengah perjalanan, ya, ada juga motivasi luar yang mungkin agak samalah ininya, apa, ee, nadanya kayak yang tadi itu, karena nilai, karena ini, itu lainlah. Seperti, ya, dulu, kan, pernah ikut MTQ juga (Informant 1/DU 12).

Translation:

My interest started to grow. I meant, it grew, but not necessarily because of this, yeah. For instance, elementary level children, perhaps due to the force from their teachers or to fulfill an assessment. If a motivation came from me, it started at my 2nd level (of Junior High School). Even though in the process, there were external motivations that were pretty much like this, what we might call, a similarity, because of an assessment, because of this, and that, like for the example back then, I ever joined MTQ as well (Informant 1/DU 12).

Furthermore, informant 2 said that he started to memorize the Qur'an from the same time, from his time in Junior High School. He said:

Ee, sekitar kelas 1 MTs-lah, kalau enggak 2 MTs, gitu (Informant 2/DU 12).

Translation:

Ah, around the 1st level of Madrasah Tsanawiyah (MTs), or the 2nd level (Informant 2/DU 12).

He also reported:

Sejak masuk pesantren sudah, sudah, sudah pengen banget bisa hafal Al-Quran (Informant 2/DU 10).

Translation:

Since I entered Islamic boarding high school, (I) wanted to memorize Al-Qur'an (Informant 2/DU 10).

\section{Theme 3: Repetition as the Method in Memorizing the Qur'an}

The technique that they used in memorizing the Qur'an was repetition. Informant 1 said:

Aa, tekniknya, ya, akhirnya, memang setiap kali kita menghafal dengan bertambahnya hafalan, dengan bertambahnya umur itu, macam-macam tekniknya. Kalau yang saya selalu terapkan sekarang, ya, itu. Dengan satu, satu apa namanya, satu wajah, satu wajah (Informant 1/DU 58).

Translation:

Ah, about the technique, yeah, at the end of the day, whenever we memorize with our increasing memorization, the older the age, the technique varies. For what I implement (on myself) personally, with that one technique, called 'satu wajah' (one direction) (Informant 1/DU 58).

On the other hand, informant 2 reported that he used repetition techniques in memorizing the Qur'an. And he said:

Kalau teknik, tergantung mood dan tergantung momen, kalau saya pribadi. Kadang-kadang cukup baca sekali, langsung dihafal. Kalau dia agak susah rupanya ayatnya, ulang, baca ulang berapa kali, baru dihafal. Kalau dia mudah, sekali pun boleh (Informant 2/DU 28).

Translation: 
The technique depends on (my) mood and (the) moment, for me personally. Sometimes to recite once is enough, (I can) immediately memorize. If the verse is quite difficult, repeat and recite several times again, then memorize it. If it is easy, once is enough (Informant 2/DU 28).

\section{RESEARCH QUESTIONS}

2. What are the difficulties faced by IIUM postgraduate students in carrying out the Qur'an memorization and working at the same time during their studies?

Based on analysis of the data from interviews, the researchers found one theme for this question, which was timing to finish memorizing the whole Qur'an.

\section{Theme 1: Timing}

Based on the data gathered from interviews, the researchers found that both two IIUM postgraduate students could complete memorizing the whole Qur'an. Informant 1 said:

Ya, Insya Allah. Karena memang, ya, apa, menghafal Al-Quran itu adalah prioritas. Jadi, ada lima jam dalam 24 jam sehari-hari saya yang di antara lima jam itu memang harus ada waktu untuk menghafal Al-Quran (Informant 1/DU 96).

Translation:

Yes, Insya Allah. Because indeed, memorizing the Qur'an is a priority. So, there are five hours from my 24 hours in which between those five hours I should allocate time to memorize Al-Qur'an (Informant 1/DU 96).

On the other hand, informant 2 was sure that he would memorize all verses of the Qur'an before he graduates master from IIUM. He said:

Insya Allah, masih sanggup. Bahkan, ditargetkan sebelum keluar dari kampus ini, UIA, harus selesai 30 juz (Informant 2/DU 52)

Translation:

Insya Allah, (I am still) be able to (do it). Even (I) put the target (on myself) before graduating from this university, IIUM, (that I) should finish (memorizing) the 30 juz (Informant 2/DU 52).

On the contrary with informant 2, informant 1 said that he did not have a target to complete the Qur'an memorization. Therefore, he would continue to memorize until he memorized all verses of the Qur'an. He said:

Belum bisa menargetkan karena, ya, mungkin membagi waktu sendiri saya masih inilah, ee, ya, karena kita, kan bela... bela... menulis itu, kan, dituntut membaca juga, gitu. Membaca bacaanbacaan untuk tesisnya itu (Informant 1/DU 88).

Translation:

(I am still) unable to target (the memorization) because, perhaps (due) to my capacity in managing time (where) I am still, um, yeah, because we are, studying, writing, we are obligated to read, right, i.e., reading the materials for the thesis (Informant 1/DU 88).

Informant 2 said that he has a target to complete the Qur'an memorization, that is, before his master's graduation. He said:

Insya Allah, masih sanggup. Bahkan, ditargetkan sebelum keluar dari kampus ini, UIA, harus selesai 30 juz (Informant 2/DU 52).

Translation: 
Insya Allah (I will be) able to manage it. Even (I) targeted it before I graduated from UIA to finish the 30 juz (Informant 2/DU 52).

Furthermore, the researchers found that both of the IIUM postgraduate students have consistency in memorizing the Qur'an every day. Informant 1 said:

Lima jam dari 24 jam yang itu ada waktu wajib untuk menghafal Al-Quran. Di antara lima jam yang... yang wajib itu, lo, Pak. Maksudnya untuk improvisasi diri, termasuk, misalnya, membaca, menulis (Informant 1/DU 98).

Translation:

Five hours from the available 24 hours is compulsory (for me) to memorize Al-Qur'an. Around the five hours, (I do) what is compulsory to do, Sir, for self-improvement, for example, reading, writing (Informant 1/DU 98).

Tapi dengan tesis, ya, satu jam (Informant 1/DU 106).

\section{Translation:}

But for the thesis, just one hour (to work on the thesis) (Informant 1/DU 106).

Informant 2 used all of his free time for memorizing Al-Qur'an. He said:

Kalau bagi saya enggak. Karena, ee, sebisa mungkin saya gunakan waktu luang itu, kalau enggak buat, kalau enggak buat, ya, kerja sama kuliah, ya, saya gunakan buat hafal Al-Quran. Kalau lagi kosong, ee, saya buka Al-Quran. Jadi, ke mana-mana harus bawa Al-Quran. Meskipun itu hanya sekadar aplikasi di handphone, saya tetap bawa Al-Quran (Informant 2/DU 72).

Translation:

For me, it is not the case. . Because, um, I use the best that I could in my spare time, if not for, if not for, working and studying matters, I use it to memorize Al-Qur'an. If I am free, I open Al-Qur'an. So, wherever I go, I shall carry Al-Qur'an. Even though it is only an app on the smartphone, I still have to bring Al-Qur'an (Informant 2/DU 72).

\section{RESEARCH QUESTIONS 3: How do IIUM postgraduate students balance the Qur'an memorization with their working together during their studies?}

Based on the data analysis from interviews, the researchers found one theme for this question. This theme describes that both do not have a special target about how many verses they memorize every day.

\section{Theme 1: Flexibility in Memorizing the Qur'an}

The researchers found that the amount of verses that they memorize from the Qur'an every day is flexible. Informant 1 said:

15 menit. Karena terlalu sedikit juga kita enggak fokus. Enggak dapat fokusnya. Kita enggak dapat, istilahnya, menyatukan hati kita sama Al-Qurannya itu enggak dapat. Kalau terlalu lama itu juga, ya, tiba-tiba ada orang datang itu juga fokus kita ini juga, teralihkan. Nah, jadi itu salah satu untuk antisipasinya adalah demikian (Informant 1/DU 132).

Translation:

15 minutes. Because too short a period will not enable us to focus, there is no focus on it (being short in time). We cannot, by the term, unite with the Qur'an; the feeling would not be grasped. Sometimes, someone comes in if the time is too long, and our focus will be distracted. So, to anticipate those situations, (I set it on) such preparation (15 minutes) (Informant 1/DU 132).

Informant 2 does not have special tricks in memorizing Al-Qur'an. He said: 
Enggak ada trik khusus. Apa, ya, enggak trik khusus. Hanya jalanin. Ketika kuliah, kuliah. Ketika ngerjain tugas, tugas. Tesis, tesis. Ketika jadwal ke perpustakaan, ke perpustakaan. Ketika jadwal ke masjid, ke masjid. Begitu terus setiap hari. Jadi, enggak ada trik-trik khusus. Ee, yang, kalau punya trik-tirik khusus, kadang-kadang, saya, bikin ribet, malah (Informant 2/DU 108).

Translation:

There are no special tricks. There are no special tricks. (I) just do it. When it is time for class, I go to class. (When it is the time for) doing assignments, (I do) assignments. (When it is the time for) going to the library, (I go). (When it is the time for) going to the mosque, (I go) to the mosque. That is the everyday routine. So, there are no special tricks. Sometimes, when using special tricks, they might complicate me more (Informant 2/DU 108).

\section{DISCUSSION}

The perception of IIUM postgraduate students on balancing the Qur'an memorization and working activities during their level of study

The initial goal of this study is to find out how IIUM postgraduate students feel about combining Qur'an memorization and work during their studies. The information was gathered through interviews with two informants, and the researchers discovered three themes: The importance of memorizing the Qur'an was described in the first theme. The second theme depicted the start of Qur'an memorization, which began in junior high school. The last theme for this study inquiry was the practice of repetition for memorizing the Qur'an. Finally, the timetable had by the pupils.

First, based on the data gathered, informant 1 mentioned that the Qur'an memorization is important. Therefore, he wanted to memorize all verses of the Qur'an during his study and work. Furthermore, informant 2 said he wants to finish his memorization of the Qur'an as soon as possible.

Secondly, both informants mentioned that they started memorization in junior high school. Informant 1 said he started from junior high school to senior high school, where he joined MTQ. On the other hand, informant 2 started from junior high school when he entered pesantren this in his pesantren.

Thirdly, both said that they used the repetition technique. Informant 1 said that he divides pages into three parts, and he reads many times until he can memorize, while informant 2 uses time limits when he sits to memorize one page at a time by repetition.

\section{The difficulties faced by IIUM postgraduate students in balancing the Qur'an memorization and working activities during their level of study}

Based on the interviews, the researchers determined the average time it took the informants to memorize all of the verses of the Qur'an. To begin, both stated that they must be able to memorize all of the Qur'an's passages. Second, informant 1 stated that he would memorize all Qur'anic verses because it was his priority, but he did not have a time frame in mind. Informant 2, on the other hand, stated that he planned to memorize all of the passages before finishing his master's degree.

\section{Balancing the Qur'an memorization and working activities during their level of study}

The researchers discovered one pattern from the interview data that answers this research question: none of these two IIUM postgraduate students limited the number of pages they memorized each day. Informant 1 stated that he would memorize the Qur'an for at least 15 minutes. Informant 2, on the other hand, would devote all of his free time to memorizing the Qur'an, and he could usually remember one page every day.

\section{CONCLUSION}

In conclusion, IIUM postgraduate students have different perspectives on how to balance memorizing the Qur'an with work duties while studying on campus. To begin with, memorizing the Qur'an is critical, even when studying and working. Another common misconception is that memorizing the Qur'an should begin in junior high school. Furthermore, the IIUM graduate students noted that repetition is a technique for remembering the Qur'an. Furthermore, the challenges encountered by IIUM postgraduate students in memorizing the Qur'an while working are related to the time required to 
memorize all verses of the Qur'an. Finally, the IIUM postgraduate students attempted to memorize the Qur'an multiple times, each time preserving their time and employing a certain technique, in this case, repetition. Every day, Informant 1 memorized the Qur'an for at least 15 minutes.

Meanwhile, informant 2 spent all of his free time memorizing the Qur'an. Most of the time, he can memorize one page in a single day. This study demonstrates that, while students have difficulty in balancing Qur'an memorization, work, and studying, Qur'an memorization is still possible with time management changes based on the intensity of the activities.

\section{Funding and Conflicts of Interest}

The author declares no funding and conflicts of interest for this research.

\section{REFERENCES}

Abdullah, N. M. S. A. N., Sabbri, F. S. M., \& Isa, R. A. M. (2018). Challenges Facing School Students in Qur'an Memorization: A Qualitative Study. In Prosiding Seminar Kebangsaan Majlis Dekan Pendidikan Universiti Awam (pp. 7-8). http://irep.iium.edu.my/77681/1/365374 NIK MD SAIFUL AZIZI NIK ABDULLAH et al.pdf.

Abdullah, N. M. S. A. N., \& Ab Rahim, F. N. B. (2021). Exploring The Challenges of Sustaining Qur'anic Memorization: A Case Study. Journal of Islamic Educational Research, 6, 1-17. http://mojes.um.edu.my/index.php/JIER/article/download/28706/13290.

Akhmar, I., Lestari, H., \& Ismail, Z. (2021). Metode Efektif Menghafal Al-Qur'an Bagi Siswa Madrasah Ibtidaiyah:. El-Mujtama: Jurnal Pengabdian Masyarakat. https://doi.org/10.47467/elmujtama.v1i1.261

Alhojailan, M. I., et al. (2012). Thematic Analysis: A Critical Review of Its Process and Evaluation. West East Journal of Social Sciences-December 2012. Volume 1 Number 1.

http://westeastinstitute.com/journals/wp-content/uploads/2013/02/4-Mohammed-IbrahimAlhojailan-Full-Paper-Thematic-Analysis-A-Critical-Review-Of-Its-Process-And-Evaluation.pdf.

Ali, A. Y. (1996). The holy Qur'an: text and translation. Kuala Lumpur: Islamic BookTrust.

Al-Qasim, A. M. (n. d.) Cara Peraktis Menghafal Alquran, trans. Abu Ziyad. Jakarta: Islam House.

Aryati, A., Azizah, N., \& Hazmin, H. (2020). Pengaruh Hafalan Al-Qur'an terhadap Prestasi Belajar Bahasa Arab Siswa. JOEAI: Journal of Education and Instruction, 3(1), 75-84.

https://journal.ipm2kpe.or.id/index.php/IOEAI/article/download/1312/889.

Aziz, J. A. (2017). Pengaruh Menghafal Al-Quran Terhadap Pembentukan Karakter Peserta Didik Di Roudhotul Atfal (RA) Jamiatul Qurra Cimahi. Golden Age: Jurnal Ilmiah Tumbuh Kembang Anak Usia Dini, 2(1), 1-15. https://doi.org/10.14421/iga.2017.21-01

Blandford. (2013). Semi-Structured Qualitative Studies. In: Soegaard, Mads and Dam, Rikke Friis (eds.). "The Encyclopedia of Human-Computer Interaction, 2nd Ed.". https://discovery.ucl.ac.uk/id/eprint/1436174/

Boyatzis, R. E. 1998. Transforming qualitative information: thematic analysis and code development. Sage Publications. https://us.sagepub.com/en-us/nam/transforming-qualitativeinformation/book7714

Creswell, J. W. (2005). Educational Research: Planning, Conducting and Evaluating Quantitative and Qualitative Research, 2nd Ed. Pearson Merrill Prentice Hall. http://www.sciepub.com/reference/69171

Driscoll, D. L. (2011). Introduction to primary research: Observations, surveys, and interviews. Writing spaces: readings on writing, 2, 153-174. Denzin, N. (1978). The Research Act: A Theoretical Introduction to Sociological Methods. New York: McGraw-Hill. https://wac.colostate.edu/books/writingspaces2/driscoll--introduction-to-primaryresearch.pdf. 
Eisner, E. W. (1991). The enlightened eye: Qualitative inquiry and the enhancement of educational practice. New York, NY: Macmillan Publishing Company. http://mehrmohammadi.ir/wpcontent/uploads/2019/07/The-Enlightened-Eye -Qualitativ-Elliot-W.-Eisner.pdf

Hamzah, N. (2005). Parental role in promoting children's Qur'anic memorization. Master thesis, IIUM. http://studentrepo.iium.edu.my/handle/123456789/3837.

Hilmi, A. B. A., et al. (2017). The Development of Al-Quran Education Module for Gifted and Talented Students: Permata Insan College Approach. Al-Qanatir: International Journal of Islamic Studies, 5(2), 22-33. https://al-qanatir.com/index.php/aq/article/download/50/44.

Ibrahim, Alhojailan, Mohammed (2012). Thematic Analysis: A Critical Review Of Its Process And Evaluation. West East Journal of Social Sciences-December 2012 Volume 1 Number 1. https://fac.ksu.edu.sa/sites/default/files/ta thematic analysis dr mohammed alhojailan.pdf

International Islamic University of Malaysia. 2021. About IIUM. IIUM. https://www.iium.edu.my/page/about-iium (Accessed 17 September 2021).

Laila, I. (2014). Penafsiran Al-Qur'an Berbasis Ilmu Pengetahuan. Epistemé: Jurnal Pengembangan Ilmu Keislaman, 9(1), 45-66. http://178.128.61.209/index.php/epis/article/view/58/53.

Ma'ruf, I. J., Hartanto, O., \& Sulaeman, E. S. (2019, June). Memorizing Al Quran Improves Quality of Life Stroke Patients with Motoric Aphasia Disorders. IOP Conference Series: Earth and Environmental Science (Vol. 292, No. 1, p. 012030). IOP Publishing. https://journals.sagepub.com/doi/full/10.1177/2050312117740990.

Monette, D.R., T.J. Sullivan and CR DeJong. (2002). Applied Social Research. Orlando, FLA: Harcourt Press.

Norman K. Denzin (1970) The Research Act: A Theoretical Introduction to Sociological Methods Aldine Publishing Company. https://www.routledge.com/The-Research-Act-A-TheoreticalIntroduction-to-Sociological-Methods/Denzin/p/book/9780202362489

Patton M. Q. (2002). Qualitative research and evaluation methods. 3rd Sage Publications; Thousand Oaks, CA: 2002. https://us.sagepub.com/en-us/nam/qualitative-research-evaluationmethods/book232962

Robert K. Yin (1984) Case Study Research: Design and Methods. SAGE Publications. https://books.google.com/books/about/Case Study Research.html?id=bA1HAAAAMAAI

Silverman, D. (1998). The Quality of Qualitative Health Research: The Open-Ended Interview and its Alternatives. Social Sciences in Health 4(2): 104-18.

Zainal, Z. (2007). Case study as a research method. Jurnal kemanusiaan, 5(1). https://jurnalkemanusiaan.utm.my/index.php/kemanusiaan/article/view/165/158. 